\title{
Research on the Construction Path Of Accounting Major in Private Universities Driven by AACSB International Certification
}

\author{
Yaqin Xu*, Ming Li \\ Wuhan Technology and Business University, Huangjiahu West Road, Hubei wuhan, China
}

Keywords: 2018 edition of the AACSB, Accounting professional construction, Certification standards, Teaching and learning, The construction of the mission, AOL

\begin{abstract}
With the deep integration of Chinese and western education concepts and teaching methods, universities have participated in the AACSB international certification in an attempt to obtain the "pass" for core competition in discipline construction. Therefore, based on the interpretation of the 2018 version of the AACSB international certification standard, and combining the characteristics of private universities, this article discusses the dimensions of "strategic management and innovation", "learning and teaching", and "accounting academic and professional participation" in private universities. Put forward the optimization path, and try to provide a reference for the construction of the accounting specialty of private colleges and universities to meet the international first-class education standards.
\end{abstract}

\section{Introduction}

After more than 30 years of development, private colleges and universities have already become an indispensable subject in the institutions of higher education. The construction of the accounting profession has trained and transported a large number of professional accounting talents for enterprises and institutions. However, in the context of frequent domestic and foreign docking in the accounting profession of private colleges and universities, it is necessary to consider how to fully align with international first-class education standards under the premise of taking root in realistic conditions. In order to improve the quality of university accounting majors and standardize the construction of majors, universities have participated in and strived to obtain the oldest and most qualified AACSB international certification, and strive to obtain "passes" to participate in international higher education competition. Therefore, studying the construction of accounting specialty in private colleges and universities driven by AACSB international certification is a topic of great practical value.

From the perspective of the theory and practice of the construction of the accounting profession, the research results of scholars at home and abroad mainly focus on the interpretation of the AACSB certification standards and the operation of the AACSB in the construction of the accounting profession. Regarding the interpretation of AACSB certification standards, Kennedy believe that AACSB is a certification institution premised on a mission [1]; Friedman pointed out that AACSB education accreditation is strict in business and accounting systems and has high standards, ranking first Globally [2]; Kenneth believe that with the sharp increase in the number of universities seeking AACSB business and accounting certification, AACSB should make its standards more global and in line with the technology-driven environment [3]. In addition, Wheeling, Elsass have conducted similar studies. Regarding the operation practice of AACSB in the construction of the accounting profession, Liu Xinhua discussed the establishment and operation of the AOL system of the 2013 version of the AACSB certification standard, taking the accounting profession as an example [4]; Gao Lifang educated in accounting profession For background comparison and study of national standards and AACSB certification standards, and put forward optimization measures from three aspects of teacher allocation, curriculum setting and teaching management [5]; Gao Lifang interpreted AACSB standards, from mission vision, expected results evaluation and resource allocation Factor analysis of strategic shortcomings of the professional development of accounting in domestic universities [6]; Ma Xiao used the AACSB certification 
practice to discuss how the School of Accounting of Southwestern University of Finance and Economics optimizes the curriculum system, strengthens the construction of teachers and builds a quality guarantee system [7]. Other scholars such as Zhuang Lijun, Liu Jianghua, and Wang Xiaoxia have also studied it from multiple perspectives.

However, an overview of the above research, it is found that the research on the concept and practice of accounting professional construction based on AACSB drive in China is obviously insufficient. The research objects are focused on public colleges and universities, and private colleges have not yet been involved. There is less research on the 2018 version of the certification standard that will be officially implemented on July 1, 2020. In terms of research methods, most of them use qualitative methods and case analysis to develop, and they do not involve interview methods and questionnaire-type quantitative methods. Based on this, this article will take private colleges and universities as an example, using qualitative and quantitative methods, to discuss the construction of the accounting profession under the AACSB international certification, with a view to improving private colleges and universities' international first-class accounting professional education standards.

\section{AACSB Overview and Interpretation of Certification Standards}

\subsection{AACSB international certification overview}

AACSB was founded in 1916. It is a non-profit organization composed of societies, business schools and other institutions. Its founding members include universities such as Harvard University, Yale University, Cornell University and Columbia. It is committed to promoting the professional level of accounting and business education, and is the world's most authoritative and influential certification institution. The types of certification include accounting certification and business certification. The average certification time is five to seven years. AACSB certification usually includes four basic processes of submitting an application-writing a report-on-site visit-maintaining the certification. Emphasize the quality of education. The AACSB certification aims to closely link colleges, students, and businesses to achieve the goal of "creating the next generation of great leaders."

\subsection{AACSB accounting certification standard}

In 1980, AACSB promulgated the accounting certification standards for the first time. With the advancement of society and the improvement of the requirements for talents, the 2013 version of the accounting certification standards was issued in 2013, including nine standards in four dimensions. The adjustment was simplified to six standards: three dimensions: "strategic management and innovation", "learning and teaching" and "accounting academic and professional participation". The latest version of the AACSB certification standard will be implemented on July 1, 2020, and the transition period is set from January 2019 to June 2020.

For the 2018 version of the AACSB accounting certification standard, first of all, the AACSB accounting certification standard highlights a strategic mission, requiring universities to focus on mission-driven teaching, student education, scientific research, and administrative management work; second, the AACSB certification standard uses "classified management "The concept of cultivating teachers is more scientific and reasonable than the traditional classification method, which helps to solve the management difficulties of teachers in colleges and universities. Finally, the AACSB certification standard emphasizes a quantitative quality assurance system.

\section{Deficiencies in the Construction of the Accounting Specialty in Private Universities}

This paper selected Wuchang Shouyi college, wenhua college, wuhan college, hankou college and wuhan technology and business college as the research objects, which ranked the top five private universities in hubei province in the "evaluation report of Chinese universities in 2019 -guidance for college entrance examination voluntary application (alumni association edition)" compiled by Cuaa.Net in January 2019. By reviewing and collecting information on the 
construction mission, the results of the construction of the accounting profession, the allocation of construction resources, and the construction of the teaching staff disclosed on the official websites of the five private colleges, the problems existing in the construction of the accounting profession in private colleges and universities were discovered.

\subsection{Construction mission is not clear, professional positioning lacks characteristics}

The first dimension of the 2018 AACSB international certification is "strategic management and innovation", which focuses on measuring whether universities have a clear mission, innovation, financial strategy and resource allocation in the construction of the accounting profession. A review of the official websites of five private colleges and universities in Hubei found that only one of the five private colleges and universities clearly disclosed the mission, vision and values of construction, and other private colleges and universities failed to express clearly. Interviews and surveys of senior managers, heads of professional accounting construction, and front-line accounting teaching workers in private universities. These positioning expressions basically match the current trend and teaching trends. However, they do not highlight the teaching characteristics of accounting majors in private colleges and universities, and their recognition is low.

\subsection{The AOL system is not perfect, and the employment trend of graduates lacks internationalization}

The second dimension of the 2018 version of the AACSB international certification is "teaching and learning", which mainly judges the construction of the quality assurance system and the training of talents in the accounting profession of universities. Only two of the five private colleges and universities have established an AOL system that operates with student learning as the core, but the effect assessment and continuous improvement contained in the AOL system are not complete. In terms of effect assessment, it is difficult for outsiders to obtain internal data of private colleges, and did not introduce independent third parties to evaluate and evaluate them; in terms of continuous improvement, the use of evaluation data to improve the "teaching and learning" program has a short-term effect, which greatly reduces the effect of improvement. In terms of training talents for the construction of the accounting profession, private colleges and universities over-emphasize graduate employment rate indicators and ignore employment structure employment trends. According to the data, the employment trends of graduates of five private colleges are based on domestic financial and accounting positions and lack internationalization.

\subsection{Inefficient teacher allocation and lack of practical experience}

The third dimension of the 2018 version of AACSB International Certification is "Accounting Academic and Professional Participation", which mainly measures the level and professionalism of the teaching staff. At present, domestic public colleges and universities require master's degrees in accounting staffing of 985 or more, and even require overseas study experience. However, from the survey of the allocation of accountants in the five private colleges and universities, the vast majority of teachers are only master's degrees. He has no background in studying abroad and lacks corporate practical experience. According to surveys, more than $60 \%$ of teachers have only accounting qualifications, junior accountants and intermediate accountants, and do not have professional certificates such as senior accountants, CMA, CPA, etc., which have stronger professionalism and more outstanding practical ability. Therefore, private colleges and universities are no obvious advantage in terms of qualifications and certificates.

\section{Optimized Path of Accounting Specialty Construction in Private Colleges and Universities Driven by AACSB International Certification}

Based on the 2018 AACSB certification standard, the internal consistency model of accounting specialty construction in private universities based on AACSB international certification is constructed, as shown below. The following feasible optimization path of accounting specialty construction is proposed based on the theoretical model (Figure 1). 


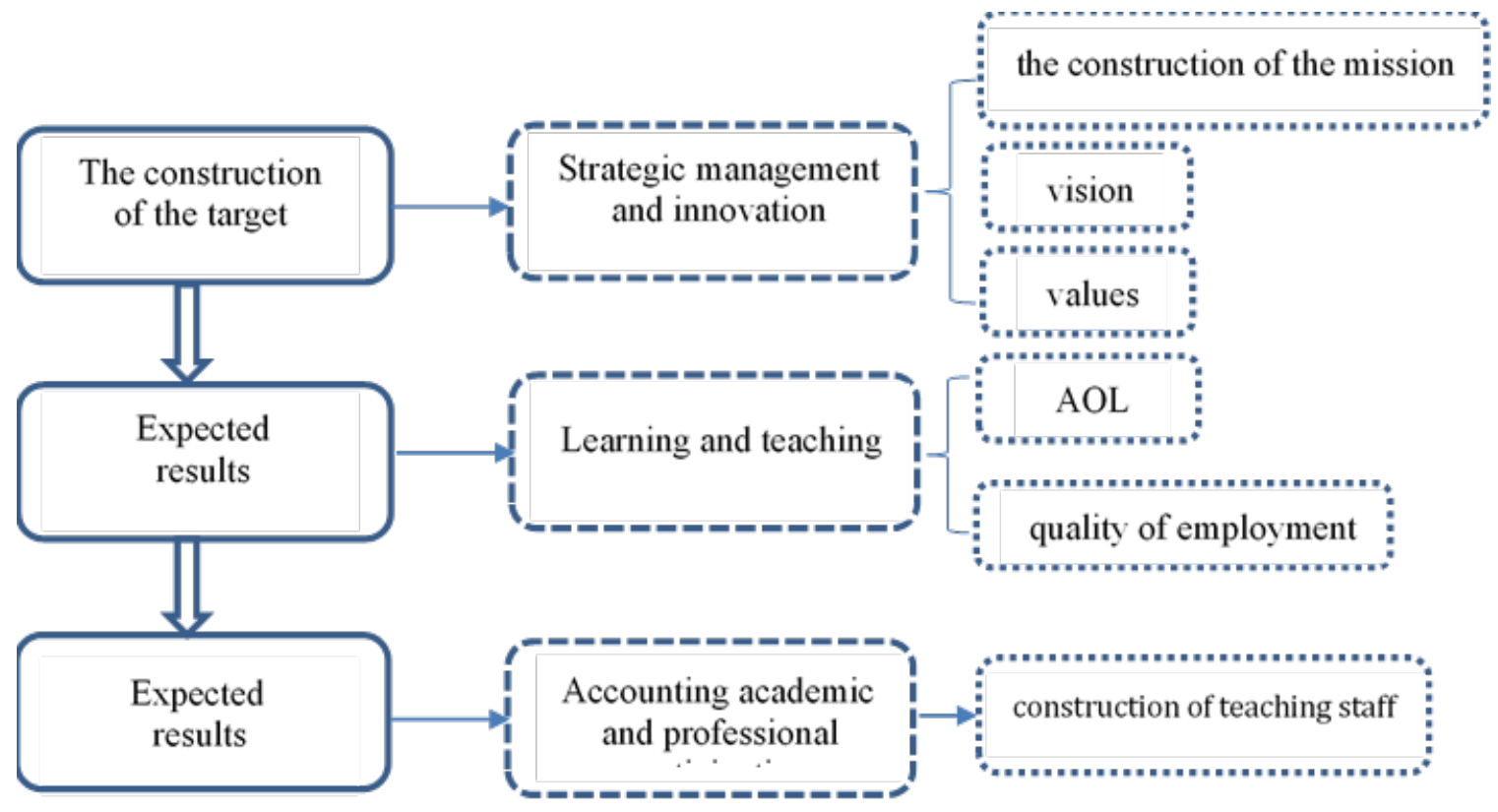

Figure 1 AACSB standard accounting professional construction theory model diagram

\subsection{Clear construction mission and individualized professional positioning}

First of all, private colleges and universities must clearly define the construction mission, which is conducive to guiding the development and direction of the construction of the accounting profession, bringing together professional teachers to work together, and establishing an integrated "strategic mission-overall planning-talent training-curriculum evaluation-quality system" as an integration Secondly, private colleges and universities must also develop personalized professional positioning, and strive to include multiple levels of teaching, academic and service content. For example, a private college uses SWOT tools to position its vision to cultivate regional talents and serve the local economy. This vision and construction mission carried out measures such as investigating regional economies, developing business cases, and strengthening horizontal cooperation between government and enterprises, which better supported the realization of the construction mission and professional positioning.

\subsection{Three-dimensional orientation and sound AOL, focusing on the quality of graduate employment}

Aiming at the problem of inadequate evaluation of the AOL system and continuous improvement, a three-dimensional orientation based on the quality of results, the number of results, and the combination of results is established. The quality of results depends on the level, social impact and economic benefits of the results published by accounting teachers. In terms of the number of achievements such as dissertations, projects, etc., the results fit to measure whether the results obtained in the construction of the accounting specialty match the mission of the construction of private universities. The establishment of AOL is to test whether the courses offered and the teaching practices can be matched with each other to promote the cultivation of talents. It is necessary to make course maps based on specific goals and quantify their standards. At the same time, private colleges and universities must also pay attention to the quality of graduate employment. For example, the accounting professional construction mission of a private college emphasizes "international" and "practical", so it is necessary to cultivate international and practical majors in the quality of graduate employment Talent. Of course, you can also consider introducing an independent third-party organization to evaluate the effectiveness of the program and improve the plan to reduce the gap between private teaching and learning and AACSB certification standards.

\subsection{Improve teacher allocation and strengthen corporate practices}

In terms of teacher allocation, private colleges and universities should combine the mission of college construction, change the concept of "emphasizing academics and neglecting practice", 
introduce diversified evaluation standards to build professional title promotion channels, and use AACSB's "classified management" concept to divide college teachers into teaching performance Responsibility support and participation in consulting and services. Private colleges are different from public colleges and universities. They pay more attention to the practicality of professional applications. Therefore, teachers must also strengthen their corporate practical ability, provide teaching, academic, and practical training, consolidate the professional advantages of private colleges, and form unique development characteristics. Of course, in supporting the teaching resources, private colleges and universities must introduce advanced technical means, such as Moodle teaching management platform, VLEs, TopHat response interaction platform, and so on.

\section{References}

[1] Kennedy M J, Horn L C. Thoughts on Ethics Education in the Business School Environment: An Interview with Dr. Jerry Trapnell, AACSB. Journal of Academic Ethics, 2007, 5(1): 77-83.

[2] Friedman H H, Kass F. The Ethics of AACSB Accreditation: Unintended Consequences. Social Science Electronic Publishing, 2016.

[3] Kenneth R. Thompson. A conversation with Milton Blood: The new AACSB standards. Academy of Management Learning \& Education, 2004, 3(4): 429-439.

[4] Liu xinxin. Establishment and operation of AOL system based on AACSB certification -- taking accounting as an example. Finance and accounting newsletter, 2018(25): 39-41.

[5] Gao lifang, Li qinghua. Thinking on undergraduate major construction of accounting -- based on national standards and guidance of international certification standards. Finance and accounting newsletter, 2016(16): 44-47.

[6] Gao lifang, Li qinghua, Zhang liying. Strategic thinking on accounting professional development —interpretation based on AACSB accounting project certification standard. Journal of finance and accounting, 2017(12): 73-78.

[7] Ma xiao, Tan hongtao. Building first-class business: AACSB certification and China's new financial and economic education. Teaching in Chinese universities, 2019(04): 58-66. 